Review

\title{
Effects of pH, High Pressure Processing, and Ultraviolet Light on Carotenoids, Chlorophylls, and Anthocyanins of Fresh Fruit and Vegetable Juices
}

\author{
Rosita Dwi Chandra*, Monika Nur Utami Prihastyanti, Diah Mustika Lukitasari \\ Ma Chung Research Center for Photosynthetic Pigments, Universitas Ma Chung, Villa Puncak Tidar N-01, Malang, East Java 65151, Indonesia
}

\section{ARTICLE INFO}

\section{Article History}

Received 01 March 2021

Accepted 29 June 2021

\section{Keywords}

Fresh juice

pigment

color

stability

non-thermal

$\mathrm{pH}$

\begin{abstract}
Health consciousness and the need to maintain immune system have increased the demand for fresh fruit and vegetable juices due to the presence of nutritional benefits including colorful pigments such as chlorophylls, carotenoids, and anthocyanins. Besides providing green, yellow, and red color in fruits and vegetables, these phytochemical compounds play an important role in health maintenance through their antioxidant activity. However, natural pigments have been known to be susceptible to adverse conditions including $\mathrm{pH}$ and temperature. Heat treatment is commonly applied in the processing of fresh juices in order to extend shelf-life. Nevertheless, thermal treatments have been reported to cause detrimental impacts on the quality of juices. Thus, non-thermal treatments such as high pressure processing (HPP) and ultraviolet (UV) light have become alternative methods to preserve the juices without high impact on nutritional and sensory characteristics. This review underlines the chlorophyll, carotenoid, and anthocyanin pigments in green, yellow, and red fresh juices obtained from several fruits and vegetables, with the influence of $\mathrm{pH}$ and non-thermal treatments (HPP and UV) on the color and stability of pigments in the fresh juices.
\end{abstract}

\section{GRAPHICAL ABSTRACT}

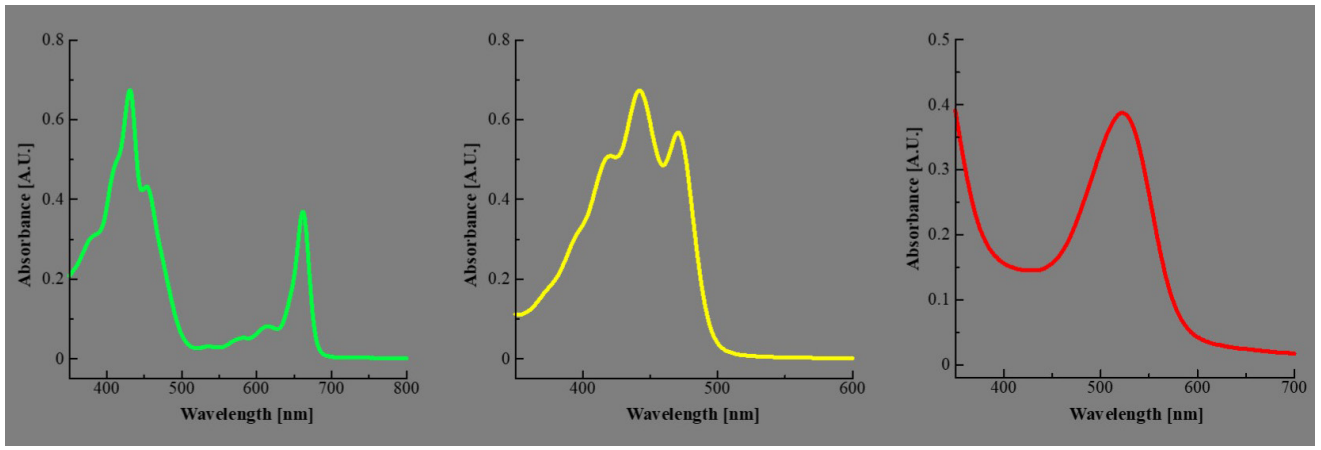

(C) 2021 The Authors. Publishing services by Atlantis Press International B.V. This is an open access article distributed under the CC BY-NC 4.0 license (http://creativecommons.org/licenses/by-nc/4.0/).

\section{INTRODUCTION}

There has been an increase in demand for fruit and vegetable juices since the beginning of 2020 due to the global corona virus disease pandemic [1]. Fruits and vegetables are considered as functional foods as they are capable of providing benefits for health due to sufficient supply of various nutrients and phytochemicals including pigments [2]. Chlorophylls, carotenoids, and anthocyanins are predominant groups of pigments that can mainly be found in fruits and vegetables, determining color of

"Corresponding author. Email: rosita.dwi@machung.ac.id

Peer review under responsibility of the International Association of Dietetic Nutrition and Safety fruits and vegetables and providing beneficial impacts on human's health. It has been reported that low intake of fruits and vegetables is among ten risk factors impacting on the global mortality while sufficient consumption of those commodities could annually save around 2.7 million lives [2,3]. Therefore, daily intake of fruits or vegetables play a pivotal role in maintaining health and boosting immune system.

Chlorophylls, a photosensitive light harvesting pigment, are primarily present in green vegetables and have shown the ability to prevent carcinogenesis through multiple chemical mechanisms [4]. They consist of a porphyrin ring chelating an $\mathrm{Mg}$ atom with a 20-carbon phytol tail at C17. This results in hydrophobic properties of chlorophylls and enable it to integrate with biological lipid 
membranes [4]. Meanwhile, carotenoids are naturally synthesized in plants and are placed in subcellular organelles (plastids) including chromoplasts and chloroplasts. In chromoplasts, carotenoids are accumulated in the form of oily droplets or crystalline while in chloroplasts they are mainly connected with proteins and play a role in photosynthesis, in association with chlorophylls [5,6]. In contrast to chlorophylls which chiefly deliver green color, carotenoids offer wider spectra of color, from yellow, orange to red. They consist of long, aliphatic and conjugated double bonded chains, playing a role as light-absorbing chromophores, and constituted with eight isoprene units of the molecular formula $\mathrm{C}_{40} \mathrm{H}_{56}$ [7], known as lipid antioxidants, singlet oxygen scavengers and potent free radical quenchers [8-10]. Besides carotenoids, red color is also provided by anthocyanins, one of the main phenolic groups in fruits and vegetables that are responsible for purple, blue, and red colors [11], which the colors are influenced by substitution in the B-ring of the aglycon and the acylation condition [12]. Anthocyanins are water-soluble glycosides and acylglycosides of anthocyanidins such as delphinidin, cyanidin, pelargonidin, petunidin, malvidin, and peonidin $[13,14]$. Thus, these pigments determine the color of fresh fruit and vegetable juices.

However, although fruits and vegetables visually exhibit similar color of juices, they provide different composition of pigments as each commodity has its own characteristics. Furthermore, as pigments are generally susceptible to adverse conditions such as temperature and $\mathrm{pH}$, the color of fresh juices can simply change during juice processing due to the degradation of pigments. Thermal pasteurisation is one of preservation methods that has been commonly used to extend the shelf-life of juices as it is able to inactivate microorganisms and undesired enzymes [15]. Nevertheless, heat exposure has resulted in undesired impacts on nutritional and sensory qualities of juices [16]. Color is one of sensory attributes that has been frequently used to determine the quality of agricultural and food products due to the direct correlation between color and flavour $[17,18]$. In fresh juices, color is directly correlated with pigments which are readily degraded by heat treatments. Therefore, non-thermal treatments such as ultraviolet (UV) light and high pressure processing (HPP) have been considered as alternative preservation methods for juices [19]. This review underlines the chlorophyll, carotenoid, and anthocyanin pigment in green, yellow, and red fresh juices obtained from several fruits and vegetables, with the influence of $\mathrm{pH}$ and non-thermal treatments (HPP and UV) on the color and stability of pigments in the fresh juices.

\section{PIGMENT COMPOSITIONS IN GREEN, YELLOW, AND RED JUICES}

The identified pigment compositions in several fruit and vegetable juices is presented in Table 1 . This includes nine commodities to represent green (Jerusalem artichoke, broccoli, Tiliacora triandra leaves, young barley shoots and leaves), yellow (carrot and orange), and red (blueberry, strawberry, red raspberry, grape, and black currant) juices. In green juices obtained from green leafy vegetables, it can be seen that chlorophyll (Chl) $a$ and $b$ are found to be predominant pigments in the juices. However, some studies show that carotenoids can also be found in green juices as these pigments present along with chlorophylls to assist chlorophylls in photosynthesis and photoaxis [20,21]. Kaszás et al. [22] reported that carotenoids including xanthophyll (lutein) were not only detected in fresh leaves of Jerusalem artichoke but also in its juice. In addition, another study revealed the presence of carotenoids such as lutein and neoxanthin along with $\mathrm{Chl} a$ and Chl $b$ in the juice of suji (Pleomele angustifolia) leaves prepared for encapsulation [23].

Carotenoids are also found to be the main pigments in yellow fresh juices. In carrot juice, provitamin A carotenoids, $\alpha$ carotene and $\beta$-carotene, appeared as the most dominant pigments, followed by $\zeta$-carotene, phytofluene, phytoene, and lutein [24]. In fresh orange juice, 5,6-epoxide carotenoids, which were cisviolaxanthin and antheraxanthin, served as the major carotenoids and contributed on yellow-orange color [25]. Epoxycarotenoids are commonly present in fresh juices. During juice preparation, the sheered plant cells release organic acids and carotenoids. With the presence of epoxycarotenoids and acidity, the isomerization of 5,6-epoxy groups into 5,8-epoxy groups occurs, even with the presence of trace amount of acid [26] and over storage at $-18^{\circ} \mathrm{C}$ [25]. Therefore, 5,8-epoxycarotenoids are more commonly found in fresh juices. As reported by Mercadante and RodriguezAmaya [27], violaxanthin $\left(5,6: 5^{\prime}, 6^{\prime}\right.$-diepoxy-5,6,5', $6^{\prime}$-tetrahydro$\beta, \beta$-carotene-3, $3^{\prime}$-diol) was not detected in fresh mango juice, although it was a major carotenoid in mango fruits. As a result, $5,8: 5^{\prime}, 8^{\prime}$-diepoxide isomer auroxanthin $\left(5,8: 5^{\prime}, 8^{\prime}\right.$-diepoxy-5, $8,5^{\prime}, 8^{\prime}$ tetrahydro- $\beta$, $\beta$-carotene- $3,3^{\prime}$-diol) which was not detected in the fresh fruit became a dominant pigment in the juice. Meanwhile, antheraxanthin $\quad\left(5,6\right.$-epoxy-5,6-dihydro- $\beta, \beta$-carotene- $3,3^{\prime}$-diol $)$ presented as a predominant carotenoid in a number of orange cultivars was not found in the juices kept for a long period of time. Consequently, 5,8-epoxide isomer of antheraxanthin which is mutatoxanthin $\quad\left(5,8\right.$-epoxy-5,8-dihydro- $\beta, \beta$-carotene- $3,3^{\prime}$-diol $)$ was discovered in the old juices [25]. Therefore, the presence of 5,8 -epoxy groups can be used to determine the age of juices, in which the higher the concentration of 5,8-epoxycarotenoids and the lower the concentration of 5,6-epoxycarotenoids, the older the age of the juices [25].

In contrast to carotenoids which become major pigments in several yellow juices, anthocyanins are generally found in red fruit juices. As presented in Table 1, it can be seen that various amount and type of anthocyanins, particularly acylglycosides of anthocyanidins, are contained in red fresh juices derived from blueberry, strawberry, red raspberry, grape, and black currant. The most diverse profile of anthocyanin pigments is shown in blueberry and grapes as most of the type of anthocyanins, dephinidin, cyanidin, petunidin, peonidin, and malvidin, are provided in the juices, while in strawberry juice there are only two anthocyanidins found which are cyanidin and pelargonidin. This shows that each red fruit exhibits a unique anthocyanin profile which differs the characteristics from each other.

According to Castañeda-Ovando et al. [38] and Khoo et al. [39], cyanidin, delphinidin, pelargonidin, peonidin, malvidin, and petunidin were the most common anthocyanidins presented in the fruit and vegetables, counting for $50 \%, 12 \%, 12 \%, 12 \%, 7 \%$, and $7 \%$, respectively. Highlighting on the red color, cyanidin, pelargonidin peonidin, and malvidin are the three anthocyanidins which contribute on that color. Cyanidin is a reddish-purple pigment which can be abundantly found in berries, red sweet potato, and purple 
Table 1 Pigment compositions present in several green, yellow, and red fruit and vegetable juices

\begin{tabular}{|c|c|c|c|c|}
\hline Fruit/vegetable & Color of juice & Pigments & Group of pigment & References \\
\hline $\begin{array}{l}\text { Jerusalem artichoke, broccoli, } \\
\text { Tiliacora triandra leaves, young } \\
\text { barley shoots and leaves }\end{array}$ & Green & $\begin{array}{l}\text { Chlorophyll } a \\
\text { Chlorophyll } b\end{array}$ & Chlorophyll & {$[22,28-30]$} \\
\hline Carrot & Yellow & $\begin{array}{l}\text { 15-cis-phytoene } \\
\text { Phytofluene isomer } 1 \\
\text { Phytofluene isomer } 2 \\
\text { Phytofluene isomer } 3 \\
\zeta \text {-carotene isomer } 1 \\
\zeta \text {-carotene isomer } 2 \\
\zeta \text {-carotene isomer } 3 \\
\zeta \text {-carotene isomer } 4 \\
\zeta \text {-carotene isomer } 5 \\
\text { all-trans- } \alpha \text {-carotene } \\
\text { all-trans- } \beta \text {-carotene } \\
\text { all-trans-lutein } \\
9 \text {-cis- } \beta \text {-carotene } \\
13 \text {-cis- } \beta \text {-carotene } \\
15 \text {-cis- } \beta \text {-carotene } \\
13,15 \text {-di-cis- } \beta \text {-carotene } \\
\text { 9-cis- } \alpha \text {-carotene } \\
13 \text {-cis- } \alpha \text {-carotene } \\
15 \text {-cis- } \alpha \text {-carotene } \\
\text { 9-cis-lutein } \\
13 \text {-cis-lutein }\end{array}$ & Carotenoid & {$[24,31]$} \\
\hline Orange & Yellow & $\begin{array}{l}\text { (all-E)-violaxanthin }+(Z) \text {-violaxanthin isomers } \\
\text { Violaxanthin isomers }+ \text { auroxanthin isomers } \\
\text { Luteoxanthin }+(Z) \text {-antheraxanthin isomer } \\
(Z) \text {-antheraxanthin isomer } \\
(Z) \text {-antheraxanthin isomer + auroxanthin } \\
(Z) \text {-luteoxanthin isomer A } \\
(Z) \text {-luteoxanthin isomer B } \\
(Z)-\zeta \text {-carotene isomer } \\
(9 Z) \text {-violaxanthin } \\
(9 Z) \text { or }\left(9^{\prime} Z\right) \text {-antheraxanthin } \\
\text { Mutatoxanthin epimer A } \\
\text { Mutatoxanthin epimer B } \\
\text { Auroxanthin } \\
\text { Lutein } \\
\text { Zeaxanthin } \\
\text { Zeinoxanthin } \\
\alpha \text {-carotene } \\
\beta \text {-cryptoxanthin } \\
\beta \text {-carotene } \\
\beta \text {-carotene }+\zeta \text {-carotene }\end{array}$ & Carotenoid & [25] \\
\hline Blueberry & Red & $\begin{array}{l}\text { Delphinidin 3-galactoside } \\
\text { Delphinidin 3-glucoside } \\
\text { Delphinidin 3-arabinoside } \\
\text { Cyanidin 3-galactoside } \\
\text { Cyanidin 3-glucoside } \\
\text { Cyanidin 3-arabinoside } \\
\text { Petunidin 3-galactoside } \\
\text { Petunidin 3-glucoside } \\
\text { Petunidin 3-arabinoside } \\
\text { Peonidin 3-galactoside } \\
\text { Peonidin 3-glucoside } \\
\text { Malvidin 3-galactoside } \\
\text { Malvidin 3-glucoside } \\
\text { Malvidin 3-arabinoside }\end{array}$ & Anthocyanin & [32-34] \\
\hline Strawberry & Red & $\begin{array}{l}\text { Pelargonidin 3-glucoside } \\
\text { Pelargonidin 3-rutinoside } \\
\text { Cyanidin 3-glucoside }\end{array}$ & Anthocyanin & {$[32,35,36]$} \\
\hline
\end{tabular}


Table 1 Pigment compositions present in several green, yellow, and red fruit and vegetable juices-Continued

\begin{tabular}{|c|c|c|c|c|}
\hline Fruit/vegetable & Color of juice & Pigments & Group of pigment & References \\
\hline Red raspberry & Red & $\begin{array}{l}\text { Cyanidin 3-sophoroside } \\
\text { Cyanidin 3-glucosyl-rutinoside } \\
\text { Cyanidin 3-rutinoside } \\
\text { Cyanidin 3-glucoside } \\
\text { Pelargonidin 3-sophoroside }\end{array}$ & Anthocyanin & {$[32,33,36]$} \\
\hline Grape & Red & $\begin{array}{l}\text { Cyanidin 3-glucoside } \\
\text { Delphinidin 3-glucoside } \\
\text { Malvidin 3-glucoside } \\
\text { Petunidin 3-glucoside } \\
\text { Peonidin 3-glucoside }\end{array}$ & Anthocyanin & {$[32,33]$} \\
\hline Black currant & Red & $\begin{array}{l}\text { Cyanidin 3-glucoside } \\
\text { Cyanidin 3-rutinoside } \\
\text { Delphinidin 3-glucoside } \\
\text { Delphinidin 3-rutinoside }\end{array}$ & Anthocyanin & {$[32,33,37]$} \\
\hline
\end{tabular}

corn $[40,41]$. Pelargonidin provides red color in several fruit and berries, while orange hue is shown in flowers [42-44]. Peonidin (3-O-methylated anthocyanidin) which is primarily contained in grapes, berries, and red wines has cherry red hue or magenta $[39,42]$. Malvidin, another $O$-methylated anthocyanidin, represents not only red pigment in red wine [45], but also purple color in some flowers [46].

\section{COLOR AND PIGMENT CONTENT OF FRESH FRUITS AND VEGETABLES AND THE JUICES}

Color has become a visual attribute used by consumers to value a product before deciding on purchase as it could help in describing the quality such as freshness of the product. It is also able to set the expectations of costumers towards the likely taste and flavour of the product [47]. It has been studied that color and flavour have strong correlation as the identification of flavour tends to decrease when colors of food products are different from the expectation [48]. For instance, there will be the tendency to describe white wine colored red using red wine odour instead of white wine odour [49]. Thus, besides influencing the flavour perception, color is one of the most important attribute that can lead consumers towards the products they expect and require, to be then purchased and consumed.

The CIELAB color scale is frequently applied for food analysis to signify color of food products. It provides $L^{*}, a^{*}, b^{*}$ coordinates, where $L^{*}$ value describes lightness, $a^{*}$ describes redness or greenness, and $b^{*}$ describes yellowness or blueness. Hue angle $\left(h^{*}\right)$, a qualitative attribute of color that involves the values of $a^{*}$ and $b^{*}$ into account, is associated with the traditional color expressions such as yellowish and reddish, through which the color of edible and descriptive part of fruits and vegetables can be represented [50]. Hence, a number of studies have applied the value of hue angle as a color attribute to associate with pigments in fruit and vegetables. Figure 1 represents hue values of several fruits and vegetables commonly processed into fresh juices in which red color is indicated with hue value $<20^{\circ}$ and $>330^{\circ}$, yellow from $20^{\circ}$ to $80^{\circ}$, while green from $80^{\circ}$ to $160^{\circ}$ [50]. In addition, to summarise the content of chlorophylls, carotenoids, and anthocyanins in those commodities, Table 2 is presented and it can be seen that carotenoids were provided in all of the presented fruits and vegetables. However, the hue values and the pigment content are subject to change when the fruits and vegetables are processed into fresh juices due to the change in $\mathrm{pH}$ and preservation treatments. The effects of those factors on the color and pigment stability of fresh juices are explained below.

\subsection{Color and Pigments of Fruit and Vegetable Juices Based on pH}

Fresh juices obtained from fruits and vegetables typically represent color with certain hue which may be changed by $\mathrm{pH}$ of juices. In relation to chlorophylls and green color, the susceptibility of chlorophylls to $\mathrm{pH}$ is clearly shown at low $\mathrm{pH}$. According to the study of Koca et al. [57], it was found that the rate constant of green color loss was increased with the decrease in $\mathrm{pH}$, indicating that the green color was sensitive at lower $\mathrm{pH}$ condition. In addition, Gunawan and Barringer [58] revealed no significant difference in green color change at $\mathrm{pH} 7$ and 8. Furthermore, Sweeney and Martin [59] found no significant decrease in chlorophyll at $\mathrm{pH}>6.8$ and argued that at higher $\mathrm{pH}$ chlorophyll degradation still occurs but at slower rate. The reason for the loss of green color during processing is chiefly contributed by the alteration of chlorophylls to pheophytins at lower $\mathrm{pH}$ due to the release of cellular acids and the synthesis of new acids [22,60]. In acid solution, the change of color from bright green to dull olive green or olive yellow occurs as result of the alteration of chlorophylls to pheophytins (the substitution of magnesium in the porphyrin ring of chlorophyll with two hydrogen ions) and further breakdown to pheophorbides (the cleavage of phytol chain of chlorophyll [60-62].

The effect of $\mathrm{pH}$ on color and pigments has also been studied in carotenoids-rich fresh juices. Yellow color of starfruit and mango juices, shown through $b^{*}$ value, was relatively constant at low $\mathrm{pH}$ (around 2) and became more obvious at higher $\mathrm{pH}$. Furthermore, starfruit juice provided hue value $120^{\circ}$ while mango juice was $109^{\circ}$ which both reduced to $89^{\circ}$ and $80^{\circ}$, respectively, when the $\mathrm{pH}$ increased, indicating the change of color [63]. In addition, freshly prepared carrot juice with $\mathrm{pH} 6.07$ and was adjusted to $\mathrm{pH} 3-8$ resulted in the reduction of total carotenoid by $26 \%$ at neutral and 

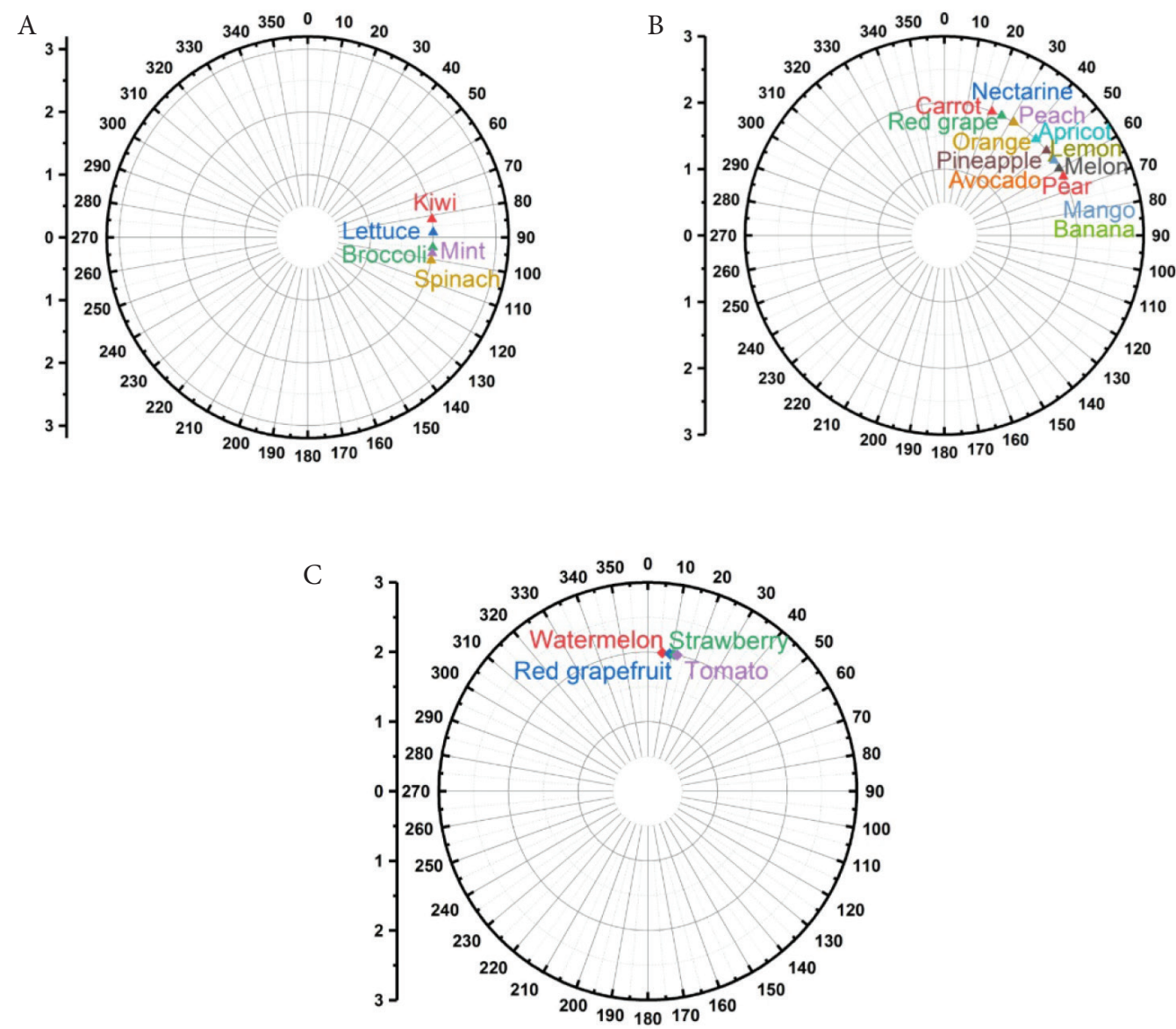

Figure 1 Hue values of several fresh fruits and vegetables commonly processed into juices obtained from the reported study of Comert et al. [50]; (A) Green: kiwi, lettuce, broccoli, mint, spinach; (B) Yellow: carrot, nectarine, red grape, peach, orange, apricot, pineapple, lemon, avocado, mango, banana, melon, pear; (C) Red: watermelon, red grapefruit, strawberry, tomato.

Table 2 Total chlorophylls, carotenoids, and anthocyanins of several fresh fruits and vegetables commonly processed into juices

\begin{tabular}{lcccc}
\hline Fruit/vegetable & $\begin{array}{c}\text { Total chlorophylls } \\
(\mathbf{m g} / \mathbf{1 0 0} \mathbf{~ g})\end{array}$ & $\begin{array}{c}\text { Total carotenoids } \\
(\mathbf{m g} / \mathbf{1 0 0} \mathbf{g})\end{array}$ & $\begin{array}{c}\text { Total anthocyanins } \\
(\mathbf{m g} / \mathbf{1 0 0} \mathbf{g})\end{array}$ & References \\
\hline Watermelon & & 4.92 & & {$[51]$} \\
Red grapefruit & & 2.12 & & {$[51]$} \\
Strawberry & 0.03 & $20-60$ & {$[51]$} \\
Tomato & 4.26 & & {$[51]$} \\
Carrot & 13.86 & 6.8 & {$[51,52]$} \\
Nectarine & 0.38 & 4.8 & {$[51,53]$} \\
Red grape & 0.11 & & {$[51,54]$} \\
Peach & & 0.32 & & {$[51]$} \\
Orange & & 0.33 & & {$[51]$} \\
Apricot & 1.30 & & {$[51]$} \\
Pineapple & 0.035 & & {$[51]$} \\
Lemon & & 0.03 & & {$[51]$} \\
Avocado & & 0.38 & & {$[51]$} \\
Mango & & 0.68 & & {$[51]$} \\
Banana & & 0.07 & & {$[51,55]$} \\
Melon & & 0.06 & & {$[51,56]$} \\
Pear & & 0.06 & & {$[51,52]$} \\
Kiwi & & 0.17 & & {$[51,56]$} \\
Lettuce & & 6.15 & \\
Broccoli & & 1.3 & \\
Mint & & $50-60$ & \\
Spinach & 0.99 & 11.5 & \\
\hline
\end{tabular}


slightly basic condition ( $\mathrm{pH} 7$ and 8 ) and an increase in the total carotenoid by $22 \%, 27 \%, 22 \%$, and $18 \%$ at $\mathrm{pH} 3-6$, respectively [64]. Meanwhile, fresh blended juices of carrot, lemon, orange, and apple with low $\mathrm{pH}(3.15,3.98$ and 4.95$)$ showed no reduction of carotenoid after 8 days of storage at $4^{\circ} \mathrm{C}$. However, at the lowest $\mathrm{pH}$ (3.15), 16\% decrease of total carotenoids occurred [64]. These findings show that, despite the degradation of carotenoids in fruit and vegetable juices was considerably low $(<25 \%)$, in acidic condition the total carotenoid content tended to increase which may be caused by the enhancement in the solubility of crystallized carotenoids available in the vacuoles of plant material [65].

Further study in the relationship between $\mathrm{pH}$ and carotenoids can be seen through the addition of acid in fresh juices. In fresh orange juice, the addition of citric acid initially accelerated the formation of 5,8-epoxy isomers, reducing the level of 5,6-epoxycarotenoids, during $48 \mathrm{~h}$ of storage. Afterward, there was a considerably decrease in the level of both epoxycarotenoids and showed no significant changes in their levels relative to the control [25]. This indicates that due to the lipophilic properties of carotenoids, these pigments were not dissolved in the juice and located in the particles of pulp, contributing on the turbidity of the juice [25]. Besides the changes in epoxycarotenoids, there were also changes in the levels of major carotenoids due to the acidified juice during storage. The levels of the dihydroxycarotenoids zeaxanthin $\left(\beta, \beta\right.$-carotene- $3,3^{\prime}$ diol) and lutein $\left(\beta, \varepsilon\right.$-carotene- $3,3^{\prime}$-diol $)$ reduced in the juice, while the amounts of the monohydroxycarotenoids $\beta$-cryptoxanthin ( $\beta, \beta$-caroten-3-ol) and zeinoxanthin $(\beta, \varepsilon$-caroten-3-ol) remained more constant [25]. Hence, the acid treatment leads to the color changes of fresh orange juice during $48 \mathrm{~h}$ of storage as it was able to be differentiated visually. The contact between the acids and the carotenoids triggers the isomerization of 5,6- to 5,8-epoxycarotenoids, changing the yellow-orange color of violaxanthin (major carotenoid in orange juice) into light yellow of 5,8:5', $8^{\prime}$-diepoxy isomer auroxanthin [25]. However, after $48 \mathrm{~h}$ of storage, the color between the control and the acidified juice was found to be not significantly different as the juices appeared visually identical at $96 \mathrm{~h}$ [25]. In contrast to this result, previous study of MeléndezMartínez et al. [66] about the enrichment of orange juice with ascorbic acid yielded in the significant color changes after $48 \mathrm{~h}$ of storage and this might be caused by the involvement of ascorbic acid in the changes of structure that preferred the association between the acids and the carotenoids in the pulp particles, accommodating the isomerization of 5,6- to 5,8-epoxycarotenoids. This shows that the color change of the yellow juices containing carotenoids is not only determined by the $\mathrm{pH}$ but also by the storage time and the type of acids.

Regarding to anthocyanins, the change of color based on $\mathrm{pH}$ conditions is also influenced by the type of anthocyanins due to an ionic nature in the molecular structure of anthocyanins [67]. In acidic condition certain type of anthocyanins exhibit red color while in neutral $\mathrm{pH}$ some of them tend to appear in purple hue. In basic $\mathrm{pH}$, the color can change into blue although this color can also be found in neutral condition. Therefore, anthocyanins, particularly cyanidin and delphinidin [44], become more stable in acidic condition. Cyanidin appears red at $\mathrm{pH}<3$, violet at $\mathrm{pH} 7$ and 8 , and blue at $\mathrm{pH}>11$ [68]. However, it also depends on the water concentration as the decrease in the concentration of water enhances the deprotonation rate of the flavylium cation which is the predominant form of anthocyanins in lower $\mathrm{pH}$ solution, reducing color stability $[42,69]$. Peonidin also exhibits cherry red hue at acidic condition and deep blue at $\mathrm{pH}$ 8; however, it was reported that it has higher stability at high $\mathrm{pH}$ than other anthocyanidins [39]. This may be caused by the increase in the proportion of flavylium cations due to the acylation of anthocyanin, as peonidin is one of the acylated anthocyanins, resulting in the retention of redness at basic condition [39].

\subsection{The Effect of Non-Thermal Treatments on the Color and Pigments of Fruit and Vegetable Juices}

\subsubsection{Ultraviolet light}

Thermal pasteurization is the most widely used method of extending the shelf life of juices due to the ability to inactivate food spoilage enzymes and microorganisms [15]. However, thermal treatment causes detrimental effects on the nutritive and sensory characteristics of juices, including the loss of color [16,70]. Therefore, non-thermal processing for preservation of juices have become interest, following the growing demands for high quality, nutritious and fresh-like food products [71]. UV-C irradiation is one of non-thermal treatments that has been used for preserving juices [72]. Presented in the range of 200-280 nm wavelength of light spectrum, UV-C lights provide germicidal effect against microorganisms including bacteria, moulds, viruses and yeasts as the lights absorbed by the DNA of microorganisms impede transcription and translation of DNA [72-75]. In addition, contrary to thermal treatment, it has been reported that the color of juices is able to be maintained under UV-C treatment [73].

As chlorophyll is susceptible to heat treatments, these treatments generate the formation of pheophytin in processed vegetables as natural organic acids and fatty acids might be released during heat treatments. In addition, the presence of chlorophyllase enzyme in green vegetables contributes on the formation of pheophorbide by cutting the phytyl group of pheophytin, resulting in olive-brown color. Besides chlorophyllase, peroxidase (POD) and lipoxygenase (LOX) enzymes also generate chlorophyll degradation in green plants [76]. Therefore, these enzymes are required to be inactivated without high process temperatures. In wheatgrass juice, it is found that the total content of chlorophyll in the juice treated using UV-C was not significantly different from the untreated juice, whereas by using thermal treatment the loss of chlorophyll occurred by $12.4 \%$ [77]. Concerning on the color of juice, by thermal treatment $\left(75^{\circ} \mathrm{C}\right.$, $15 \mathrm{~s})$, the lighter-reddish change in color appeared in wheatgrass juice as a result of the conversion of chlorophyll into pheophytins, with $a^{*}(-2.90)$ and $L^{*}(17.65)$, while in the control, $a^{*}$ and $L^{*}$ value were -6.63 and 19.81, respectively. Meanwhile, under UV-C treatment $\left(69.2 \mathrm{~mJ} / \mathrm{cm}^{2}\right)$ there was no significant different in color, with $a^{*}(-6.15)$ and $L^{*}(22.39)$ [77]. This indicates that UV-C treatment could maintain the color and chlorophyll content of green juice.

The ability of UV treatment in retaining color of juices was also shown in several fresh yellow juices made from orange, pineapple, and orange/carrot blend $[73,74,78]$. According to the study of Bhat et al. [79], starfruit juice which was exposed under UV light at $2.158 \mathrm{~J} / \mathrm{m}^{2}$ for 30 and $60 \mathrm{~min}$ resulted in the increase of $L^{*}$ value with time, indicating the more transparent juice due 
to the degradation of coloured polymers responsible for enzymatic browning. Another study of Ibarz et al. [80] provided the decrease of $a^{*}$ and $b^{*}$ values in the same treatment of apple, peach, and lemon juices with different browning degree. The decrease of these values implies the destruction of melanoidin polymers as browning is shown through the increase of $a^{*}$ and $b^{*}$ values, shifting the color from green to reddish and blue to yellowish, respectively $[80,81]$. Besides color shifting, the increase in brightness of juices following the exposure time of UV was also observed, indicating that the browning of the fruit juices was counteracted by UV light. It is argued that the most influential factors to inactivate enzymatic browning caused by the activity of polyphenol oxidase (PPO) and POD enzymes using UV light are exposure time, temperature, dose, wavelength, juice composition, and soluble solids $[19,80,82]$. Meanwhile, under heat treatment, the lightness of carrot juice was reported to decrease. In addition, the value of $a^{*}$ and $b^{*}$ were also found to decrease with the increase in temperature and heating time, indicating the color shifting to be more greenish and bluish. Following this, the hue value showed the significant decrease, turning the color to be lighter, from orange to yellow [31]. Munsch et al. [83] reported that the alteration of color in carrot juice during processing can be associated not only with the content of carotenoid but also the formation of cis carotenoid isomers. Hence, the preservation using UV-C light could retain the color of juices containing carotenoids by inactivating the activity of enzymes responsible for enzymatic browning (PPO and POD) and limiting the formation of cis carotenoid isomers.

In addition, related to carotenoid content, the change of this coloured compound content has been revealed in several studies. The minor reduction of total carotenoid content was found in pineapple juice during UV treatment at $53.42 \mathrm{~mJ} / \mathrm{cm}^{2}$, and the amount was still significantly higher compared to the thermal treatment. Interestingly, it was increased within 14 days of storage [84]. The other increase result is presented in the study conducted by Nornisa et al. [85] which shows an increase in total carotenoid content in orange, carrot, and celery juice blend when the samples were treated under UV-C for certain duration of time, by $84 \%$ for $30 \mathrm{~min}$ and $3 \%$ for $60 \mathrm{~min}$ of exposure. The enhancement of total carotenoids by $35 \%$ was still found after 7 days of storage particularly at UV-C treatment for $15 \mathrm{~min}$. An increase in the carotenoid extraction during storage may be caused by the inactivation of enzymes responsible for the deterioration of carotenoids $[85,86]$. However, to be noted that effects of UV-C treatment may vary among the juices and it highly depends on the amount of UV-C light absorbed by the products as the major components of fruit juices may limit the absorption of UV-C $[87,88]$.

In several red juices containing anthocyanins, UV light treatment resulted in the slight decrease in total anthocyanin content in pomegranate juice by $8.4 \%$ at $62.4 \mathrm{~kJ} / \mathrm{L}$, while $23.6 \%$ occurred under heat treatment [89]. The similar trend of anthocyanin loss was also exhibited in red grape juice, in which the higher loss occurred when the juice was subjected to thermal treatment (11.9\%), compared to $8.7 \%$ by UV light at $25.2 \mathrm{~kJ} / \mathrm{L}$ [90]. In watermelon juice, UV treatment at $37.5 \mathrm{~kJ} / \mathrm{L}$ yielded in the maintenance of the redness ( $a^{*}$ value) during 37 days of storage [91]. The retention of red color may be caused by the presence of phenolic compounds which are able to stabilise anthocyanins, preventing the degradation of anthocyanins during UV-C exposure [92]. Phenolic compounds are complexing agents or copigments which are able to stabilize anthocyanins in plants through molecular copigmentation mechanism [93]. Besides phenols, a copigment could be one of alkaloids, flavonoids, organic acids, amino acids, polysaccharides, metals, nucleotides, and anthocyanins themselves [94]. This stabilization mechanism occurs through the association between electron pi systems in copigments with electronpoor flavylium ion, providing protection from the nucleophilic addition of water on the flavylium ion so that the formation of colourless pseudobase resulting in color loss is prevented [95]. In addition, the complexation of an anthocyanin with a copigment causes the wavelength shift of maximum absorbance (a bathochromic shift) and the increase in color intensity (a hyperchromic effect) [96]. However, discoloration of pigments due to photo degradation of anthocyanins may occur during long-term exposure of UV-C light, shown in cranberry and grape juices [97]. As reported by Koutchma [72], at $253.7 \mathrm{~nm}$, photons of UV light are absorbed by organic molecules, affecting conjugated (doublering and aromatic-ring molecules) and disulphide bonds and reducing the content of anthocyanins. During thermal treatment, anthocyanins form colorless or undesirable brown-colored polymeric pigments, although these color may also be found during UV treatment. The polymeric colour value in pomegranate juice was increased from $11.3 \%$ to $14.2 \%$ after UV-C treatment at $62.35 \mathrm{~J} / \mathrm{mL}$, whereas it reached to $24.5 \%$ after thermal treatment [89], showing that red color was more retained by UV treatment. Meanwhile, the change in anthocyanin profile during $\mathrm{UV}$ treatment can be seen in pomegranate juice. There were six pigments provided in this juice, i.e. delphinidin-3-glucoside, delphinidin-3,5-diglucoside, cyanidin-3-glucoside and cyanidin3,5-diglucoside as major pigments, as well as pelargonidin-3glucoside and pelargonidin-3,5-diglucoside as minor pigments. At $62.35 \mathrm{~J} / \mathrm{mL}$, the highest loss provided by delphinidin-3glucoside and the lowest by pelargonidin-3-glucoside [89].

\subsubsection{High pressure processing}

High pressure processing is a non-thermal alternative that has been applied for fruit and vegetable juices preservation through enzyme inactivation and microbial destruction with relatively slight changes in nutritional and sensory quality due to its minimal impact on covalent bonds [70,98]. Noncovalent bonds such as ionic, hydrogen, and hydrophobic bonds are reported to be very sensitive to pressure $[99,100]$. In addition, molecular weight of food components also determines the effect of pressure exposure on the quality of food products. Components with high molecular weight particularly components important for functionality determination such as proteins are considered to be pressure sensitive, while low molecular weight food compounds especially those responsible for nutritional and sensory quality are pressure insensitive $[99,100]$. Therefore, it has become an alternative to conventional thermal processing technology as it is able to preserve the natural freshness of juices.

Concerning on green juices, the content of chlorophylls was able to be retained in spinach juice during HPP which might be caused by the lack of disruption of the chlorophyll-protein complexes photosystem II [101]. Furthermore, the total chlorophyll was reported to be slightly increased during high pressure treatment in wheatgrass 
and cucumber juice $[77,102]$, which was probably caused by the release of chlorophyll from plant cells with time of treatment [103]. However, although there was an increase in the amount of chlorophyll in wheatgrass juice, under high pressure $500 \mathrm{MPa}$ for $1 \mathrm{~min}$, the color of juice was reported to be not significant different from the control and also those treated using UV-C [77]. Nevertheless, PPO and POD enzymes are known to be moderately stable to high pressure but it is dependent on the source of the enzymes $[104,105]$. Therefore, to prevent browning that may appear during storage, combination of techniques with thermal treatment or the other non-thermal treatments such as UV-C have been developed and applied in preservation of juices [19,105].

In yellow juices, HPP treatment has been found to cause a significant impact on carotenoids due to the pressure levels applied. In accordance to Stinco et al. [24], the highest carotenoid degradation $(41 \%)$ in carrot juice was provided by the HPP at the low pressure $(300 \mathrm{MPa})$, while the higher pressure $(600 \mathrm{MPa})$ resulted in the lower degradation of carotenoids (26\%). As the carotenoid content impacted by the treatment, the change of color will follow. Observing the lightness $\left(L^{*}\right)$ of the juice, the low pressure ( $300 \mathrm{MPa}$ ) yielded lower $L^{*}$ compared to that treated with higher pressure $(600 \mathrm{MPa})$, which means that darker color of juice was provided by juice treated with lower pressure and this was caused by the enzymatic browning due to the activity of PPO and POD enzymes [24]. Besides, the color alteration in carrot juice was also caused by the degradation of pigments (particularly $\zeta$-carotene) as the low pressure still allowed the exposure of the pigments to oxygen, enzymes and other agents [24]. This indicates that low pressure cannot prevent the alteration of the color especially during storage as the amount of pressure may be insufficient to inactivate the enzymes. Therefore, as high pressure alone, in certain samples, is considered insufficient to inactivate the enzymes, emerging techniques of combination with another treatment is required in the application of HPP in the preservation of juices.

Meanwhile, in the studies related to anthocyanins, HPP has resulted in limited effect on the degradation of anthocyanins and visual color differences compared to thermal processing. However, significant differences of total anthocyanin content and visual color are detected during storage. Thermal processing of strawberry and raspberry juices at $80-140^{\circ} \mathrm{C}$ for $20 \mathrm{~min}$ was found to have impact on the significant decrease of cyanidin-3-glucoside, pelargonidin3-glucoside, and pelargonidin-3-arabinoside, while at $140^{\circ} \mathrm{C}$ almost all anthocyanins content was degraded [106]. Subjected to HPP treatment, pelargonidin-3-glucoside and pelargonidin-3rutinoside in raspberries and strawberries were found to be stable at $800 \mathrm{MPa}$ [107]. Nevertheless, temperatures of treatment have been noticed to play a crucial role in the stability of anthocyanins. Anthocyanins treated with HPP up to $600 \mathrm{MPa}$ at room temperature experienced no significant change of content, while when the temperature was increased up to $70^{\circ} \mathrm{C}, 25 \%$ of anthocyanins were lost $[108,109]$. This loss was reported to be $20 \%$ higher compared to the conventional thermal processing at the same temperature which indicates that HPP combined with higher temperatures escalates the degradation of anthocyanins [110].

The similar effect of combination of HPP with thermal treatment on the color dan anthocyanin content of juices has also been proven in other studies. Torres et al. [111] revealed that orange juice treated with $600 \mathrm{MPa}$ at $20^{\circ} \mathrm{C}$ for 15 min exhibited $99 \%$ retention of cyanidin-3-glucoside. In pomegranate juice, treatment of HPP at $400 \mathrm{MPa}\left(25^{\circ} \mathrm{C}, 5 \mathrm{~min}\right)$ resulted in $37 \%$ losses of total anthocyanins content [112]. This implies that slightly higher temperature had impact on the higher loss of anthocyanins, although, the level of pressure applied was lower. HPP (400-700 MPa) coupled temperature treatment $\left(20-100^{\circ} \mathrm{C}\right)$ which was applied in strawberry and raspberry juices for 20 min resulted in the loss of cyanidin-3glucoside, pelargonidin-3-glucoside, pelargonidin-3-arabinoside, cyanidin-3-sophorosdie, and cyanidin-3-rutinoside by $80 \%$ at $>80^{\circ} \mathrm{C}$ and $23 \%$ at $<80^{\circ} \mathrm{C}$ [106]. High pressure and/or temperatures induce the conversion of monomeric anthocyanins to more condensed components, resulting in the formation of a new pyran ring by cycloaddition, changing the color of juice $[109,113]$. Meanwhile, related to the pressure-time exposure, a higher and longer pressure (400-600 MPa, 2-15 min) applied in Chinese bayberry juice resulted in the significant reduction of $a^{*}, b^{*}$ and $L^{*}$ values which means that the color of juice became less red and tended to reddish brown after HPP treatment [114]. Therefore, the application of high pressure in fresh juices should be taken into account when it is combined with temperature and time exposure. The advantages of application using HPP can be achieved if the juices treated with pressure not more than $600 \mathrm{MPa}$ at cold and room temperature although the enzyme inactivation cannot be achieved at the mild temperature. Furthermore, the combination with temperature above $50^{\circ} \mathrm{C}$ should be avoided as thermal degradation and condensation reaction of anthocyanins would be accelerated [113].

\section{CONCLUSION}

The change of $\mathrm{pH}$ that occurred during juice processing as well as the application of HPP and UV light as non-thermal treatment to preserve fresh fruit and vegetable juices were found to provide effect on the content of chlorophylls, carotenoids, and anthocyanins, along with the color of the juices. Low $\mathrm{pH}$ solution seemed to obviously affect the color of fresh juices containing chlorophylls, on the contrary to those containing carotenoids and anthocyanins where the color was able to be more retained. In the application of UV light, most of the studies reported that the reduction of pigment content and the alteration of color in the juices were able to be impeded, even during storage, due to the inactivated PPO and POD enzymes. However, it should be noted that the effect of UV treatment may vary among the juices and it highly depends on the amount of UV light absorbed by the products which is determined by exposure time, temperature, dose, wavelength, juice composition, and soluble solids. On the other hand, under the sole HPP treatment, the color of juices was still found to change during storage as high pressure was insufficient to inactivate the enzymes. Therefore, it is suggested to combine HPP with other non-thermal methods as they have been proven to preserve color and minimize the degradation of pigments.

\section{CONFLICTS OF INTEREST}

The authors declare they have no conflicts of interest. 


\section{AUTHORS' CONTRIBUTION}

RDC designed the concept, wrote, and revised the manuscript. MNUP and DML contributed to correct the manuscript.

\section{REFERENCES}

[1] Borsellino V, Kaliji SA, Schimmenti E. COVID-19 drives consumer behaviour and agro-food markets towards healthier and more sustainable patterns. Sustainability 2020;12:8366.

[2] Khoo HE, Prasad KN, Kong KW, Jiang Y, Ismail A. Carotenoids and their isomers: color pigments in fruits and vegetables. Molecules 2011;16:1710-38.

[3] World Health Organization (WHO). Fruit, vegetables and NCD disease prevention. Available from: http://www.who.int/ dietphysicalactivity/media/en/gsfs_fv.pdf (last accessed January 10, 2021) [Internet].

[4] Hsu CY, Chao PY, Hu SP, Yang CM. The antioxidant and free radical scavenging activities of chlorophylls and pheophytins. Food Nutr Sci 2013;4:1-8.

[5] Bartley GE, Scolnik PA. Plant carotenoids: pigments for photoprotection, visual attraction, and human health. Plant Cell 1995; 7:1027-38.

[6] van den Berg H, Faulks R, Fernando Granado H, Hirschberg J, Olmedilla B, Sandmann G, et al. The potential for the improvement of carotenoid levels in foods and the likely systemic effects. J Sci Food Agric 2000;80:880-912.

[7] Armstrong GA, Hearst JE. Carotenoids 2: genetics and molecular biology of carotenoid pigment biosynthesis. FASEB J 1996;10:228-37

[8] Demmig-Adams B, Gilmore AM, Adams WW. Carotenoids 3: in vivo functions of carotenoids in higher plants. FASEB J 1996; 10:403-12.

[9] Cunningham FX, Gantt E. Genes and enzymes of carotenoid biosynthesis in plants. Annu Rev Plant Physiol Plant Mol Biol 1998;49:557-83.

[10] Hirschberg J. Carotenoid biosynthesis in flowering plants. Curr Opin Plant Biol 2001;4:210-18.

[11] Melo MJ, Pina F, Andary C. Anthocyanins: nature's glamorous palette. In: Stevens CV, editor. Handbook of natural colorants. New York: John Wiley \& Sons, Ltd.; 2009, pp. 135-50.

[12] Cortez R, Luna-Vital DA, Margulis D, de Mejia EG. Natural pigments: stabilization methods of anthocyanins for food applications. Compr Rev Food Sci Food Saf 2016;16:180-98.

[13] Dia VP, Wang Z, West M, Singh V, West L, de Mejia EG. Processing method and corn cultivar affected anthocyanin concentration from dried distillers grains with solubles. J Agric Food Chem 2015;63:3205-18.

[14] Trouillas P, Sancho-García JC, De Freitas V, Gierschner J, Otyepka M, Dangles O. Stabilizing and modulating color by copigmentation: insights from theory and experiment. Chem Rev 2016;116:4937-82.

[15] Rawson A, Patras A, Tiwari Noci F, Koutchma T, Brunton N. Effect of thermal and non thermal processing technologies on the bioactive content of exotic fruits and their products: review of recent advances. Food Res Int 2011;44:1875-87.

[16] Plaza L, Sánchez-Moreno C, Elez-Martínez P, de Ancos B, Martín-Belloso O, Pilar Cano M. Effect of refrigerated storage on vitamin $\mathrm{C}$ and antioxidant activity of orange juice processed by high-pressure or pulsed electric fields with regard to low pasteurization. Eur Food Res Technol 2006;223:487-93.

[17] Pérez-López AJ, Beltran F, Serrano-Megías M, López DS, Carbonell-Barrachina GA. Changes in orange juice color by addition of mandarin juice. Eur Food Res Technol 2006;222: 516-20.

[18] Hashimoto A, Muramatsu T, Suehara Ki, Kameoka S, Kameoka T. Color evaluation of images acquired using open platform camera and mini-spectrometer under natural lighting conditions. Food Packag Shelf Life 2017;14:26-33.

[19] Koutchma T, Popović V, Ros-Polski V, Popielarz A. Effects of ultraviolet light and high-pressure processing on quality and health-related constituents of fresh juice products. Compr Rev Food Sci Food Saf 2016;15:844-67.

[20] LaBorde LF, Von Elbe JH. Zinc complex formation in heated vegetable purees. J Agric Food Chem 1990;38:484-7.

[21] Fernandes AS, Nogara GP, Menezes CR, Cichoski AJ, Mercadante AZ, Jacob-Lopes E, et al. Identification of chlorophyll molecules with peroxyl radical scavenger capacity in microalgae Phormidium autumnale using ultrasound-assisted extraction. Food Res Int 2017;99:1036-41.

[22] Kaszás L, Kovács Z, Nagy E, Elhawat N, Abdalla N, DomokosSzabolcsy E. Jerusalem artichoke (Helianthus Tuberosus L.) as a potential chlorophyll source for humans and animals nutrition. Environ Biodiv Soil Secur 2018;2:1-9.

[23] Chandra RD, Indrawati R, Heriyanto H, Brotosudarmo THP, Limantara L. Isolation, encapsulation, stability and characteristics of thylakoid from suji leaves (Pleomele angustifolia) as natural food coloring agent. Indonesia J Nat Pigm 2019;1:53-9.

[24] Stinco CM, Szczepańska J, Marszałek K, Pinto CA, Inácio RS, Mapelli-Brahm P, et al. Effect of high-pressure processing on carotenoids profile, colour, microbial and enzymatic stability of cloudy carrot juice. Food Chem 2019;299:125112.

[25] Meléndez-Martínez AJ, Escudero-Gilete ML, Vicario IM, Heredia FJ. Effect of increased acidity on the carotenoid pattern and colour of orange juice. Eur Food Res Technol 2010;230: 527-32.

[26] Rodriguez-Amaya DB. A guide to carotenoid analysis in foods. Washington, D.C.: ILSI Press; 2001, pp. 1-71.

[27] Mercadante AZ, Rodriguez-Amaya DB. Effects of ripening, cultivar differences, and processing on the carotenoid composition of mango. J Agric Food Chem 1998;46:128-30.

[28] Weemaes CA, Ooms V, Van Loey AM, Hendrickx ME. Kinetics of chlorophyll degradation and color loss in heated broccoli juice. J Agric Food Chem 1999;47:2404-9.

[29] Weerawatanakorn M, Rojsuntornkitti K, Pan MH, Wongwaiwech D. Some phytochemicals and anti-inflammation effect of juice from Tiliacora triandra leaves. J Food Nutr Res 2018;6:32-8.

[30] Blicharz-Kania A, Andrejko D, Kluza F, Rydzak L, Kobus Z. Assessment of the potential use of young barley shoots and leaves for the production of green juices. Sustainability 2019;11:3960.

[31] Chen BH, Peng HY, Chen HE. Changes of carotenoids, color, and vitamin A contents during processing of carrot juice. J Agric Food Chem 1995;43:1912-18.

[32] Obón JM, Díaz-García MC, Castellar MR. Red fruit juice quality and authenticity control by HPLC. J Food Comp Anal 2011;24:760-71.

[33] Goiffon JP, Mouly PP, Gaydou EM. Anthocyanic pigment determination in red fruit juices, concentrated juices and syrups using liquid chromatography. Anal Chim Acta 1999;382:39-50. 
[34] Prior RL, Lazarus SA, Cao G, Muccitelli H, Hammerstone JF. Identification of procyanidins and anthocyanins in blueberries and cranberries (Vaccinium spp.) using high-performance liquid chromatography/mass spectrometry. J Agric Food Chem 2001;49:1270-6.

[35] Jakobek L, Šeruga M, Medvidović-Kosanović M, Jovanović IN. Anthocyanin content and antioxidant activity of various red fruit juices. Deutsche Lebensmittel-Rundschau 2007;103: 58-64.

[36] Stój A, Malik A, Zdzisław T. Comparative analysis of anthocyanin composition of juices obtained from selected species of berry fruits. Pol J Food Nutr Sci 2006;56:401-7.

[37] Bermúdez-Soto MJ, Tomás-Barberán FA. Evaluation of commercial red fruit juice concentrates as ingredients for antioxidant functional juices. Eur Food Res Technol 2004;219:133-41.

[38] Castañeda-Ovando A, de Lourdes Pacheco-Hernández M, PáezHernández ME, Rodríguez JA, Galán-Vidal CA. Chemical studies of anthocyanins: a review. Food Chem 2009;113:859-71.

[39] Khoo HE, Azlan A, Tang ST, Lim SM. Anthocyanidins and anthocyanins: colored pigments as food, pharmaceutical ingredients, and the potential health benefits. Food Nutr Res 2017; 61:1361779.

[40] Seeram NP, Momin RA, Nair MG, Bourquin LD. Cyclooxygenase inhibitory and antioxidant cyanidin glycosides in cherries and berries. Phytomedicine 2001;8:362-9.

[41] Cevallos-Casals BA, Cisneros-Zevallos L. Stoichiometric and kinetic studies of phenolic antioxidants from andean purple corn and red-fleshed sweetpotato. J Agric Food Chem 2003;51: 3313-19.

[42] Bąkowska-Barczak A. Acylated anthocyanins as stable, natural food colorants - a review. Pol J Food Nutr Sci 2005;14/55:107-16.

[43] Robinson GM, Robinson R. A survey of anthocyanins. II. Biochem J 1932;26:1647-64.

[44] Jaakola L. New insights into the regulation of anthocyanin biosynthesis in fruits. Trends Plant Sci 2013;18:477-83.

[45] Mazza G, Francis FJ. Anthocyanins in grapes and grape products. Crit Rev Food Sci Nutr 1995;35:341-71.

[46] Tanaka Y, Tsuda S, Kusumi T. Metabolic engineering to modify flower color. Plant Cell Physiol 1998;39:1119-26.

[47] Vilela A, Cosme F. Drink red: phenolic composition of red fruit juices and their sensorial acceptance. Beverages 2016;2:29.

[48] Roth HA, Radle LJ, Gifford SR, Clydesdale FM. Psychophysical relationships between perceived sweetness and color in lemonand lime-flavored drinks. J Food Sci 1988;53:1116-19.

[49] Morrot G, Brochet F, Dubourdieu D. The color of odors. Brain Lang 2001;79:309-20.

[50] Cömert ED, Mogol BA, Gökmen V. Relationship between color and antioxidant capacity of fruits and vegetables. Curr Res Food Sci 2020;2:1-10.

[51] Bhagwat S, Haytowitz DB. USDA database for the flavonoid content of selected foods. Release 3.2 (November 2015). 2016. Available from: https://data.nal.usda.gov/dataset/usda-databaseflavonoid-content-selected-foods-release-32-november-2015. (last accessed January 10, 2021) [Internet].

[52] Sánchez C, Baranda AB, de Marañón IM. The effect of high pressure and high temperature processing on carotenoids and chlorophylls content in some vegetables. Food Chem 2014; 163:37-45.

[53] Wu X, Beecher GR, Holden JM, Haytowitz DB, Gebhardt SE, Prior RL. Concentrations of anthocyanins in common foods in the United States and estimation of normal consumption. J Agric Food Chem 2006;54:4069-75.

[54] Fu L, Xu BT, Xu XR, Gan RY, Zhang Y, Xia EQ, et al. Antioxidant capacities and total phenolic contents of 62 fruits. Food Chem 2011;129:345-50.

[55] McGhie TK, Ainge GD. Color in fruit of the genus actinidia: carotenoid and chlorophyll compositions. J Agric Food Chem 2002;50:117-21.

[56] Curutchet A, Dellacassa E, Ringuelet JA, Chaves AR, Viña SZ. Nutritional and sensory quality during refrigerated storage of fresh-cut mints (Mentha $\times$ piperita and M. spicata). Food Chem 2014;143:231-8

[57] Koca N, Karadeniz F, Burdurlu HS. Effect of pH on Chlorophyll degradation and colour loss in blanched green peas. Food Chem 2007;100:609-15.

[58] Gunawan MI, Barringer SA. Green colour degradation of blanched broccoli (Brassica oleracea) due to acid and microbial growth. J Food Process Preserv 2000;24:253-63.

[59] Sweeney JP, Martin ME. Stability of chlorophyll in vegetables as affected by pH. Food Technol 1961;15:263-6.

[60] Minguez-Mosquera MI, Garrido-Fernandez J, Gandul-Rojas B. Pigment changes in olives during fermentation and brine storage. J Agric Food Chem 1989;37:8-11.

[61] Gupte SM, El-Bisi HM, Francis FJ. Kinetics of thermal degradation of chlorophyll in spinach puree. J Food Sci 1964;29: $379-82$.

[62] Heaton JW, Marangoni AG. Chlorophyll degradation in processed foods and senescent plant tissues. Trends Food Sci Technol 1996;7:8-15.

[63] Muhammad Zahir SAD, Yahaya OKM, Omar AF. Correlating the natural color of tropical fruit juice with its $\mathrm{pH}$. Color Res Appl 2020;46:467-76.

[64] Bell T, Alamzad R, Graf BA. Effect of $\mathrm{pH}$ on the chemical stability of carotenoids in juice. Proc Nutr Soc 2016;75:E94.

[65] Ahn JW, Kim KJ. Crystal structure of 1'-OH-carotenoid 3,4desaturase from nonlabens dokdonensis DSW-6. Enzym Microb Technol 2015;77:29-37.

[66] Meléndez-Martínez AJ, Britton G, Vicario IM, Heredia FJ. The complex carotenoid pattern of orange juices from concentrate. Food Chem 2008;109:546-53.

[67] Turturică M, Oancea AM, Râpeanu G, Bahrim G. Anthocyanins: naturally occurring fruit pigments with functional properties. Ann Univ Dunarea de Jos Galati. Fascicle VI: Food Technol 2015;39:9-24.

[68] Torskangerpoll K, Andersen ØM. Colour stability of anthocyanins in aqueous solutions at various $\mathrm{pH}$ values. Food Chem 2005;89:427-40.

[69] Coutinho IB, Freitas A, Maçanita AL, Lima JC. Effect of water content on the acid-base equilibrium of cyanidin-3-glucoside. Food Chem 2015;172:476-80.

[70] Patras A, Brunton NP, O'Donnell C, Tiwari BK. Effect of thermal processing on anthocyanin stability in foods; mechanisms and kinetics of degradation. Trends Food Sci Technol 2010; 21:3-11.

[71] Patil S, Bourke P, Frias JM, Tiwari BK, Cullen PJ. Inactivation of Escherichia coli in orange juice using ozone. Innov Food Sci Emerg Technol 2009;10:551-7.

[72] Koutchma T. Advances in ultraviolet light technology for non-thermal processing of liquid foods. Food Bioprocess Technol 2009;2:138-55. 
[73] Tran MTT, Farid M. Ultraviolet treatment of orange juice. Innov Food Sci Emerg Technol 2004;5:495-502.

[74] Caminiti IM, Noci F, Morgan DJ, Cronin DA, Lyng JG. The effect of pulsed electric fields, ultraviolet light or high intensity light pulses in combination with manothermosonication on selected physico-chemical and sensory attributes of an orange and carrot juice blend. Food Bioprod Process 2012;90:442-8.

[75] Franz CMAP, Specht I, Cho GS, Graef V, Stahl MR. UV-Cinactivation of microorganisms in naturally cloudy apple juice using novel inactivation equipment based on Dean vortex technology. Food Control 2009;20:1103-7.

[76] Yilmaz C, Gökmen V. Chlorophyll. In: Caballero B, Finglas P, Toldrá F, editors. Encyclopedia of food and health, vol. 2. Oxford: Academic Press; 2016, pp. 37-41.

[77] Ali N, Popović V, Koutchma T, Warriner K, Zhu Y. Effect of thermal, high hydrostatic pressure, and ultraviolet-C processing on the microbial inactivation, vitamins, chlorophyll, antioxidants, enzyme activity, and color of wheatgrass juice. J Food Process Eng 2020;43:e13036.

[78] Chia SL, Rosnah S, Noranizan MA, Wan Ramli WD. The effect of storage on the quality attributes of ultraviolet-irradiated and thermally pasteurised pineapple juices. Int Food Res J 2012;19: 1001-10.

[79] Bhat R, Ameran SB, Voon HC, Karim AA, Tze LM. Quality attributes of starfruit (Averrhoa carambola L.) juice treated with ultraviolet radiation. Food Chem 2011;127:641-4.

[80] Ibarz A, Pagán J, Panadés R, Garza S. Photochemical destruction of color compounds in fruit juices. J Food Eng 2005;69:155-60.

[81] Lozano JE. Kinetics of non enzymatic browning in model systems simulating clarified apple juice. Lebensmittel Wissenschaft und Technologie 1991;24:355-60.

[82] Sampedro F, Phillips J, Fan X. Use of response surface methodology to study the combined effects of UV-C and thermal processing on vegetable oxidative enzymes. LWT - Food Sci Technol 2014;55:189-96.

[83] Munsch MH, Simard RE, Girard JM. Relationships in colour and carotene content of carrot juices. Can Inst Food Sci Technol J 1983;16:173-8.

[84] Goh SG, Noranizan M, Leong CM, Sew CC, Sobhi B. Effect of thermal and ultraviolet treatments on the stability of antioxidant compounds in single strength pineapple juice throughout refrigerated storage. Int Food Res J 2012;19:1131-6.

[85] Nornisa N, Somasundram C, Razali Z. The effects of UV-C treatment on the quality of orange, carrot and celery juice blend. J Food Sci Nutr 2018;1:1-7.

[86] Glevitzky M, Pop M, Brusturean GA, Bogdan I, Calisevici M, Perju D. Efficient use of antioxidants to preserve fruit juice. Rev Chim 2008;59:1291-5.

[87] Shah NNAK, Shamsudin R, Rahman RA, Adzahan NM. Fruit juice production using ultraviolet pasteurization: a review. Beverages 2016;2:22.

[88] Fan X, Geveke DJ. Furan formation in sugar solution and apple cider upon ultraviolet treatment. J Agric Food Chem 2007;55:7816-21.

[89] Pala CU, Toklucu AK. Effect of UV-C light on anthocyanin content and other quality parameters of pomegranate juice. J Food Comp Anal 2011;24:790-5.

[90] Pala ÇU, Toklucu AK. Microbial, physicochemical and sensory properties of UV-C processed orange juice and its microbial stability during refrigerated storage. LWT - Food Sci Technol 2013;50:426-31.

[91] Feng M, Ghafoor K, Seo B, Yang K, Park J. Effects of ultraviolet-C treatment in teflon -coil on microbial populations and physicochemical characteristics of watermelon juice. Innov Food Sci Emerg Technol 2013;19:133-9.

[92] Bąkowska A, Kucharska AZ, Oszmiański J. The effects of heating, UV irradiation, and storage on stability of the anthocyanin-polyphenol copigment complex. Food Chem 2003;81: 349-55.

[93] Davies AJ, Mazza G. Copigmentation of simple and acylated anthocyanins with colorless phenolic compounds. J Agric Food Chem 1993;41:716-20.

[94] Mazza G, Brouillard R. The mechanism of co-pigmentation of anthocyanins in aqueous solutions. Phytochemistry 1990; 29:1097-102.

[95] Mazza G, Brouillard R. Recent developments in the stabilization of anthocyanins in food products. Food Chem 1987;25: 207-25.

[96] Mazza G, Miniati, E. Anthocyanins in fruits, vegetables and grains. Florida: CRC Press; 1993, p. 384.

[97] Guerrero-Beltrén JA, Barbosa-Cénovas GV. Inactivation of Saccharomyces cerevisiae and Polyphenoloxidase in mango nectar treated with UV light. J Food Prot 2006;69:362-8.

[98] Oey I, Lille M, Van Loey A, Hendrickx M. Effect of highpressure processing on colour, texture and flavour of fruitand vegetable-based food products: a review. Trends Food Sci Technol 2008;19:320-8.

[99] Barba FJ, Terefe NS, Buckow R, Knorr D, Orlien V. New opportunities and perspectives of high pressure treatment to improve health and safety attributes of foods. A review. Food Res Int 2015;77:725-42.

[100] Butz P, Fernández García A, Lindauer R, Dieterich S, Bognár A, Tauscher B. Influence of ultra-high pressure processing on fruit and vegetable products. J Food Eng 2003;56:233-6.

[101] Wang R, Ding S, Hu X, Zhang Y. Stability of chlorophyllprotein complex (photosystem II) in processed spinach: effect of high hydrostatic pressure. Int J Food Prop 2017; 20:S3177-S88.

[102] Zhao L, Wang S, Liu F, Dong P, Huang W, Xiong L, et al. Comparing the effects of high hydrostatic pressure and thermal pasteurization combined with nisin on the quality of cucumber juice drinks. Innov Food Sci Emerg Technol 2013; $17: 27-36$.

[103] Krebbers B, Matser AM, Koets M, Van den Berg RW. Quality and storage-stability of high-pressure preserved green beans. J Food Eng 2002;54:27-33.

[104] Chakraborty S, Baier D, Knorr D, Mishra HN. High pressure inactivation of polygalacturonase, pectinmethylesterase and polyphenoloxidase in strawberry puree mixed with sugar. Food Bioprod Process 2015;95:281-91.

[105] Kaushik N, Srinivasa Rao P, Mishra HN. Process optimization for thermal-assisted high pressure processing of mango (Mangifera indica L.) pulp using response surface methodology. LWT - Food Sci Technol 2016;69:372-81.

[106] Verbeyst L, Hendrickx M, Van Loey A. Characterisation and screening of the process stability of bioactive compounds in red fruit paste and red fruit juice. Eur Food Res Technol 2012;234:593-605. 
[107] Garcia-Palazon A, Suthanthangjai W, Kajda P, Zabetakis I. The effects of high hydrostatic pressure on $\beta$-glucosidase, peroxidase, and polyphenoloxidase in red raspberry (Rubus idaeus) and strawberry (Fragaria $\times$ ananassa). Food Chem 2004;88:7-10.

[108] Barba FJ, Esteve MJ, Frigola A. Physicochemical and nutritional characteristics of blueberry juice after high pressure processing. Food Res Int 2013;50:545-9.

[109] Corrales M, Butz P, Tausher B. Anthocyanin condensation reactions under high hydrostatic pressure. Food Chem 2008;110:627-35.

[110] Tiwari BK, O’Donnell CP, Cullen PJ. Effect of non-thermal processing technologies on the anthocyanin content of fruit juices. Trends Food Sci Technol 2009;20:137-45.
[111] Torres B, Tiwari BK, Partas A, Cullen PJ, Brunton N, O’Donnel CP. Stability of anthocyanins and ascorbic acid of high pressure processed blood orange juice during storage. Innov Food Sci Emerg Technol 2011;12:93-7.

[112] Ferrari G, Maresca P, Ciccarone R. The effects of high hydrostatic pressure on the polyphenols and anthocyanins in red fruit products. Procedia Food Sci 2011;1:847-53.

[113] Marszałek K, Woźniak Ł, Kruszewski B, Skąpska S. The effect of high pressure techniques on the stability of anthocyanins in fruit and vegetables. Int J Mol Sci 2017;18:277.

[114] Su G, Zhu S, Xu M, Ramaswamy HS, Lin Y, Yu Y. Pressure degradation kinetics of anthocyanin pigment and visual color of chinese bayberry juice. Int J Food Prop 2016;19:443-53. 